\title{
Serum Melatonin Levels in Patients with Family Mediterranean Fever
}

\author{
Ailevi Akdeniz Ateşi Olan Hastalarda Serum Melatonin Düzeyleri \\ (1) Ayhan Kul, (1) Nurinnisa Öztürk, (1) Köksal Sarıhan, (1) Fatih Baygutalp \\ Atatürk University Faculty of Medicine, Department of Physical Medicine and Rehabilitation, Erzurum, Turkey
}

\section{Abstract}

Objective: Melatonin (MLT) has been reported to play a role in the immunopathogenesis and aetiology of many chronic inflammatory diseases. Therefore, we aimed to investigate the possible relationship between disease severity and serum MLT levels in patients with Familial Mediterranean fever (FMF).

Materials and Methods: A total of 30 patients diagnosed with FMF who had experienced no episodes for at least 1 month (mean age, 36.4 \pm 12.2 years; range, 19-68 years), including 14 men and 16 women, and 30 healthy controls (mean age, 38.4 \pm 12.5 years; range, $19-65$ years), 12 men and 18 women, matched for age and gender, were included in this study. Demographic data, laboratory data and clinical characteristics of the participants were recorded and serum MLT levels were determined. In addition, the relationship between serum MLT level and disease severity was evaluated.

Results: A significant difference was observed between the groups in terms of serum MLT levels $(p<0.05)$. However, there were no significant relationships between serum MLT levels and demographic data, such as sex and age, and body mass index, erythrocyte sedimentation rate, C-reactive protein and fibrinogen levels and disease severity scores of the FMF patients. There was a statistically significant difference in serum MLT levels between patients having a history of acute arthritis $(n=7)$ and those without arthritis $(n=23),(p=0.019)$.

Conclusion: Our findings suggest that MLT may play a possible role in the immunopathogenesis of FMF and those with a history of FMFrelated arthritis. However, because the immune regulatory role of MLT is very complex and the mechanisms are not yet fully understood, we think that more comprehensive studies in the future are needed to confirm our findings.

Keywords: Familial Mediterranean fever, melatonin, arthritis, relationship

\section{$\ddot{O z}$}

Amaç: Melatoninin (MLT) birçok kronik enflamatuvar hastalığın immünopatogenezinde ve etiyolojisinde rol oynayabileceği bildirildiğinden dolayı, çalışmamızda ailevi akdeniz ateşi (AAA) olan hastaların serum MLT seviyelerinin belirlenerek hastalık şiddeti ile arasında olası bir ilişki olup olmadığını incelemeyi amaçladık.

Gereç ve Yöntem: Çalışmaya AAA hastalığı tanısı konulan ve en az 1 aydır (ortalama yaş, 36,4 1 12,2 yıl; aralık, 19-68 yıl) atak geçirmeyen 14

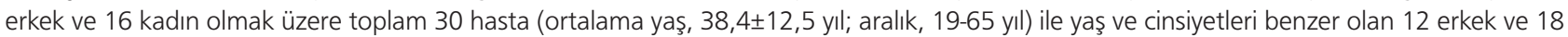
kadın toplam 30 sağlıkı kontrol (ortalama yaş 38,4 12,5 yıl; yaş aralığı; 19-65 yıl) bulunmaktaydı. Katılımcıların demografik verileri, laboratuvar ve klinik özellikleri kaydedilerek, serum MLT seviyeleri belirlendi. Ayrıca serum MLT seviyesi ile hastalık şiddeti arasındaki ilişki değerlendirildi. Bulgular: Gruplar arasında serum MLT seviyeleri açısından anlamlı fark olduğu belirlendi $(p<0,05)$. AAA hastalarının cinsiyet, yaş ve vücut kitle indeksi gibi demografik verileri, eritrosit sedimentasyon hızı, C-reaktif protein ve fibrinojen değerleri ve hastalık şiddet skoru ile serum MLT seviyesi arasında anlamlı bir ilişki bulunmadı. AAA hastalarında artrit varlı̆ına göre; akut artrit öyküsü olanlar ( $n=7$ kişi) ile artriti olmayanlar ( $n=23$ kişi) arasında serum MLT düzeyleri açısından istatistiksel olarak anlamlı fark bulundu ( $p=0,019)$.

Sonuç: Bulgularımız MLT'nin AAA'nın immünopatogenezinde ve AAA'ya bağlı artrit öyküsü olanlarda olası bir rol oynadığına dair kanıt sunmaktadır. Ancak MLT'nin immün düzenleyici rolü çok karmaşık ve mekanizmaları henüz tam olarak anlaşılamadığından dolayı bulgularımızın gelecekte daha kapsamlı araştırmalarla desteklenmesi gerektiğini düşünüyoruz.

Anahtar kelimeler: Ailevi akdeniz ateşi, melatonin, artrit, ilişki 


\section{Introduction}

Familial Mediterranean fever (FMF) is a recurrent and selflimiting hereditary auto inflammatory disease characterized by fever and painful polyserositis attacks with a very intense acute phase response (1). Although it was reported that B and $\mathrm{T}$ lymphocyte dysfunction and immunological abnormalities related to the production of proinflammatory cytokines, incorrectly regulated immune response and over-response to very small stimuli or to the delayed deactivation of the immune response play role in the course of the disease, the pathophysiology of the disease it is not clear (2-4). It has also been reported that decreased antioxidant capacity and impaired oxidant/antioxidant balance may be associated with FMF pathogenesis (5).

Melatonin (MLT) is the hormone that is secreted from the pineal gland and regulates the circadian rhythm, and it is thought that as a result of disruption of the circadian rhythm, it will deteriorate in immune response, abnormal immune cells will occur and may lead to FMF attacks (6-8). Many studies of MLT have emphasized its antioxidant properties as one of the most potent endogenous free radical scavengers $(9,10)$. In addition, MLT has been reported to have immunomodulatory and anti-inflammatory functions in clinical studies $(11,12)$. However, the immune regulatory role of MLT is very complex and its mechanisms are not yet fully understood (13). Because of these properties, it has been suggested that MLT may play a role in the immunopathogenesis and etiology of many chronic inflammatory diseases and can also be used in their treatment. In addition, due to the relationship between circadian MLT secretion and the rhythmic symptoms and symptoms of some chronic inflammatory diseases, it may have a role in the pathophysiology of these diseases (13). However, there is a study in the literature examining the relationship between FMF disease and MLT, and the relationship between MLT and disease severity was not evaluated in that study.

In our study; we aimed to investigate the possible relationship between disease severity and serum MLT levels in patients with FMF.

\section{Materials and Method}

This study was conducted between November 2019 and December 2019 at Atatürk University Faculty of Medicine, Department of Physical Medicine and Rehabilitation and
Department of Rheumatology. The study protocol was approved by the Atatürk University Faculty of Medicine Ethics Committee (decision no: 17, date: 07.11.2019). A written informed consent was obtained from each subject. The study was conducted in accordance with the principles of the Declaration of Helsinki.

A total of 30 FMF patients diagnosed based on the criteria defined by Livneh et al. (14) and 30 healthy individuals with similar age and gender were included. All patients were diagnosed and evaluated by the same physician. None of the patients had an FMF attack. Patients who did not have an attack for at least 1 month were included in the study. The control group was constituted of healthy individuals.

In our study, FMF patients with additional immunological, rheumatologic or systemic disease, acute or chronic infection, complete urinalysis and abnormal biochemical results in blood analysis were excluded from the study.

Gender, age, body mass index (BMI), duration of disease, duration and dose of colchicine were recorded. Eighteen patients were on $1 \mathrm{mg} /$ day oral colchicine treatment and 12 patients were on $1.5 \mathrm{mg} /$ day oral colchicine treatment. Disease severity of FMF patients was evaluated in clinical examination.

The FMF disease severity scores were calculated based on age at disease onset $(>31,21-31,11-20,6-10$, and $<6$ years, respectively, 0, 1, 2, 3, 4 points), number of attacks per month, $(1,2,3$ points if $<1,1-2,>2$ respectively), arthritis status ( 2 and 3 points respectively if acute or protracted), amyloidosis status (3 points if present), colchicine dose $(1,1.5,2$ and $>2 \mathrm{mg}$, respectively, 1, 2, 3 and 4 points) and the presence or absence of erysipelas-like erythema at the time of admission. Scores of $3-5,6-8$, and $\geq 9$ were considered to reflect mild, moderate and severe disease, respectively (15). Distribution of the number of patients according to the scores obtained from disease severity parameters is shown in Table 1.

Healthy controls and FMF patients were rested in sitting position between 8.00-9.00 in the morning, and blood samples were obtained from antecubital region by using a vacutainer. Venous blood samples were stored in biochemistry tube for C-reactive protein (CRP) and MLT measurements and in hemogram tubes with ethylenediaminetetraacetic acid for erythrocyte sedimentation rate (ESR) measurements. Biochemistry samples were centrifuged at $4.000 \mathrm{rpm}$ for 15 minutes after the clotting process at room temperature was completed and serum

Table 1. Distribution of the number of patients according to scores obtained from disease severity parameters

\begin{tabular}{|l|l|l|l|l|l|}
\hline \multirow{2}{*}{ Number of patients according to disease severity parameters } & \multicolumn{4}{l|}{ Disease severity score } \\
\cline { 2 - 6 } & $\mathbf{0}$ point & $\mathbf{1}$ point & $\mathbf{2}$ point & $\mathbf{3}$ point & $\mathbf{4}$ point \\
\hline $\mathrm{n}$ (Age at disease onset; 0-4 point) & 6 & 11 & 8 & 4 & 1 \\
\hline $\mathrm{n}$ (Number of attacks per month; 1-3 point) & - & 21 & 9 & - & - \\
\hline $\mathrm{n}$ (Arthritis status; 2/3 point) & 23 & - & 7 & - & - \\
\hline $\mathrm{n}$ (Erysipelas-like erythema status; 0/2 point) & 25 & - & 5 & - & - \\
\hline $\mathrm{n}$ (Amyloidosis status; 0/3 point) & 27 & - & - & 3 & - \\
\hline $\mathrm{n}$ (Colchicine dose; 1-4 point) & - & 18 & 12 & - & - \\
\hline $\mathrm{n}$ : Number of patients & & & & \\
\hline
\end{tabular}


samples were aliquoted for MLT measurement and stored until analyzed at $-80{ }^{\circ} \mathrm{C}$. The analysis was performed in the Medical Biochemistry Laboratory of our hospital.

The ESR (0-20 mm/h) was measured with the Western Green method using Interrliner XN (Sysmex Corporation, Kobe, Japan) automatic ESR analysis device and the CRP $(0-5 \mathrm{mg} / \mathrm{mL})$ was quantitatively measured with the immunoturbidometric method using Beckman Coulter AU5800 autoanalyser (Beckman Coultr Inc. Ca, USA). Fibrinogen (mg/dL) levels were measured by Clauss clotting method on STA Compact (Diagnostica Stago, France) coagulation analyzer. MLT levels were analyzed by enzyme-linked immunosorbent assay (ELISA) method on Dynex brand automated ELISA reader device (Dynex Technologies Headquarters, Chantilly, USA) according to the standard protocol recommended by SunLong brand (Cat No: SL1169Hu, Sunlung Biotech Co., Ltd., HangZhou, China). The intra-assay cofficient of variation (CV) value of the kit was below $10 \%$ and the inter-assay CV was below $12 \%$.

\section{Statistical Analysis}

In our study, power analysis for serum MLT level was performed at $95 \%$ power and $95 \%$ confidence interval. The mean values for the MLT level were $23 \pm 2.8 \mathrm{pg} / \mathrm{mL}$ for the patient group and $16.4 \pm 3.8 \mathrm{pg} / \mathrm{mL}$ for the control group. Statistical analysis was performed using SPSS 20.0 (SPSS, Chicago IL, United States). Results were given as mean \pm standard deviation (SD) and minimum (min) - maximum (max). The suitability of the parameters to normal distribution was evaluated by KolmogorovSmirnov test. One-Way ANOVA test and t-test (independent samples t-test, or student t-test) were used to compare normal distribution parameters. The non-normal distribution parameters were compared with Mann-Whitney U test. Pearson correlation analysis was used for correlation analysis.

\section{Results}

A total of 30 patients (14 males and 16 females, mean age $36.4 \pm 12.2$ years; range 19 to 68 years), with FMF disease, and 30 healthy controls ( 12 males and 18 females, mean age $38.4 \pm 12.5$ years; range 19 to 65 years), were included in the study.

Demographic characteristics, laboratory characteristics, disease duration, disease severity score and serum MLT levels of patients and healthy individuals are shown in Table 2. There was no statistically significant difference between the groups in terms of age, gender, BMI, ESR, CRP and fibrinogen levels. The mean disease duration in the patient group was $10 \pm 11$ years (range $1-50$ years). The mean disease severity score was $5 \pm 2$ There was a significant difference between the groups in terms of serum MLT levels ( $p<0.05)$, (Table 2).

There was no significant relationship between serum MLT level and demographic data such as gender, age and BMI, ESR, CRP and fibrinogen values, disease severity score of FMF patients (Table 3).

When the arthritis, FMF disease severity score parameters were assessed, there was a statistically significant difference in serum MLT levels between patients with a history of acute arthritis $(n=7)$ and those without arthritis $(n=23) \quad(p=0.019)$, but no significant difference was found in other clinical severity parameters (Figure 1).

\section{Discussion}

The aim of the study was to investigate the clinical and physopathological effect of MLT hormone on FMF. Our study was the first to evaluate the relationship between serum MLT levels and disease severity. In our study, we found that serum MLT levels were higher in the FMF patient group than in the control group. In addition, serum MLT levels of FMF patients with a history of arthritis were significantly higher than those without a history of arthritis.

Circadian rhythm allows the body to adapt to environmental changes. Disruption of this rhythm usually has a negative effect. For example; Jet Lag syndrome, which is a collection of spontaneous symptoms that lasts for a few days as a result of

Table 2. Demographic, laboratory and clinical characteristics of Familial Mediterranean fever patients and healthy controls

\begin{tabular}{|c|c|c|c|}
\hline & Patients $(n=30)$ & Controls $(n=30)$ & p \\
\hline Gender (f/m) & $16 / 14$ & $12 / 18$ & 0.602 \\
\hline Age (mean \pm SD) & $36.4 \pm 12.2$ & $38.4 \pm 12.5$ & 0.541 \\
\hline BMI $\left(\mathrm{kg} / \mathrm{m}^{2}\right)$ & $26.3 \pm 4$ & $27 \pm 3.5$ & 0.484 \\
\hline Disease duration [(mean \pm SD, (minimum-maximum), year)] & $10 \pm 11(1-50)$ & - & - \\
\hline $\mathrm{ESR}($ mean $\pm \mathrm{SD})(\mathrm{mm} / \mathrm{h})$ & $13.2 \pm 13.9$ & $11.2 \pm 8.1$ & 0.52 \\
\hline $\operatorname{CRP}($ mean $\pm \mathrm{SD})(\mathrm{mg} / \mathrm{mL})$ & $11.4 \pm 12.5$ & $6.8 \pm 5.6$ & 0.218 \\
\hline Fibrinogen $(\mathrm{mg} / \mathrm{dL})$ & $334 \pm 76.4$ & $306 \pm 70.4$ & 0.144 \\
\hline Serum melatonin level (mean $\pm \mathrm{SD})(\mathrm{pg} / \mathrm{mL})$ & $23 \pm 2.8$ & $16.4 \pm 3.8$ & $0.001 * *$ \\
\hline Disease severity scores & $5.2 \pm 2$ & - & - \\
\hline
\end{tabular}


Table 3. Demographic characteristics of Familial Mediterranean fever patients and the relationship between serum melatonin levels and erythrocyte sedimentation rate, C-reactive protein, fibrinogen and disease severity score

\begin{tabular}{|l|l|l|}
\hline & $\mathbf{r}$ & $\mathbf{p}$ \\
\hline Age $(\mathrm{mean} \pm \mathrm{SD})$ & 0.064 & 0.626 \\
\hline BMI $\left(\mathrm{kg} / \mathrm{m}^{2}\right)$ & -0.028 & 0.83 \\
\hline ESR $(\mathrm{mean} \pm \mathrm{SD})(\mathrm{mm} / \mathrm{h})$ & -0.077 & 0.556 \\
\hline $\mathrm{CRP}(\mathrm{mean} \pm \mathrm{SD})(\mathrm{mg} / \mathrm{mL})$ & 0.131 & 0.318 \\
\hline Fibrinogen $(\mathrm{mg} / \mathrm{dL})$ & 0.162 & 0.216 \\
\hline Disease severity scores & -0.142 & 0.455 \\
\hline
\end{tabular}

SD: Standard deviation, BMI: Body mass index, ESR: Erythrocyte sedimentation rate, CRP: C-reactive protein, $p<0.05$ : Statistically significant difference between groups

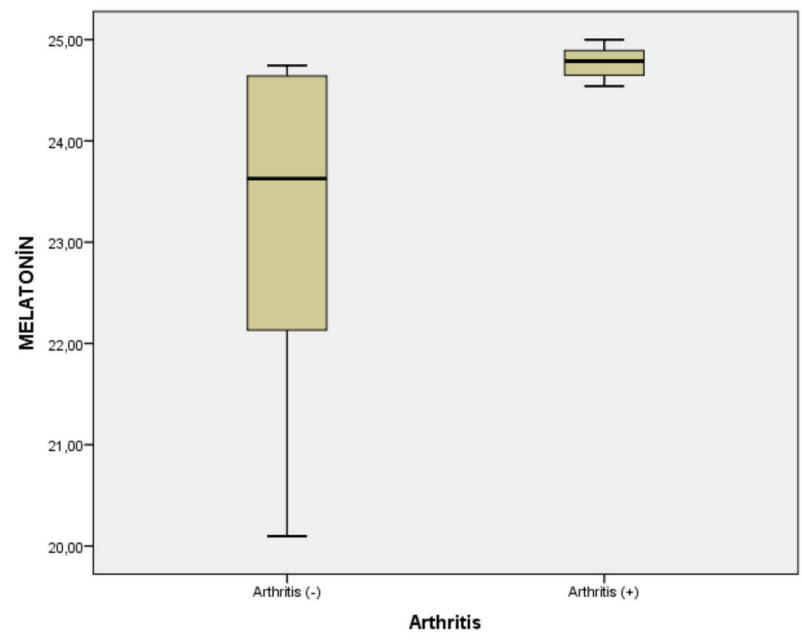

Figure 1. Serum melatonin levels of Familial Mediterranean fever patients according to arthritis history

disruption of the circadian rhythm, resembles the FMF attacks that last for several days and usually end with a pattern of onset and termination. Therefore, it is stated that disruption of the circadian rhythm may cause FMF attacks $(16,17)$. In addition, common factors such as physical and emotional stress or highfat diet may lead to disruption of the circadian rhythm and FMF attacks. It also suggests that MLT, the main regulatory hormone of the circadian rhythm, may have a possible role in the pathophysiology or clinic of FMF, which is known as a neutrophilrelated disease, since MLT causes monocytes, natural killer cells, and in particular neutrophil activation $(18,19)$.

MLT levels in FMF were evaluated by Musabak et al. (13) serum MLT levels were reported to be significantly higher in both acute exacerbations and non-exacerbations than in the control group, similar to our study. Again, no significant correlation was found between ESR and fibrinogen levels and serum MLT levels. It has been suggested that MLT may play a role in the immunopathogenesis of many autoimmune and auto inflammatory diseases including FMF. Our study makes a contribution to the literature and differs from the study of Musabak et al. (13) in terms of evaluating the relationship between serum MLT levels and disease severity and detecting higher serum MLT levels in the group with arthritis history. Makay and Unsal (16) have suggested that changes in circadian rhythm may disrupt the immune response and affect the functions of the hypothalamic-pituitary-adrenal (HPA) axis, an important component of the neuroendocrine and immune system. Furthermore, they reported that any dysfunction in the HPA axis would affect the release of proinflammatory cytokines in the immune system and that HPA axis could have an active role in FMF attack $(16,20,21)$.

In our study, FMF patients who were not at attack were evaluated. Therefore, ESR, CRP and fibrinogen values were within normal limits and were similar to those of the control group. In addition, similar to literature, there was no significant relationship between MLT levels and demographic data such as age, gender and BMI (22). In the literature, in patients with rheumatoid arthritis (RA) and ankylosing spondylitis (AS), it was reported that serum MLT levels were significantly higher than in the control group, similar to our results $(13,23)$. These results may suggest that MLT may have a role in the pathophysogenesis of FMF disease and subclinical inflammation. In addition, many studies reported that MLT may increase as a compensatory response to inflammation by stating its antioxidant and antiinflammatory properties (24).

In the literature, as a result of studies investigating the relationship between rhythmic symptoms and signs in some autoimmune diseases such as RA and AS and the secretion of circadian MLT; It has been reported that serum MLT levels are higher than control groups and there is a significant relationship between disease activities and serum MLT levels and it is reported that MLT may play a role in the pathophysogenesis of these diseases $(25,26)$. In these studies, it was stated that high serum MLT levels in the morning may be a cause of symptoms such as stiffness and joint swelling in patients with arthritis $(10,25,26)$. It was also reported that MLT may play a role in the formation of a more active inflammatory response during the night by increasing the synthesis of proinflammatory cytokines (16). However, there are studies reporting that high MLT values in the morning are not associated with disease activity (22). In addition, there are studies reporting that serum MLT levels are lover in patients with systemic lupus erythematosus, psoriasis, and multiple sclerosis in compared to healthy individuals (27). This suggest that it is not clear how and where MLT plays a role due to the different immunopathogenetic processes involved in the formation of autoimmune diseases. In the light of these results; we can say that the immunopathological and clinical effects of MLT have not been fully elucidated due to the fact that different immunopathogenetic mechanisms are effective in different autoimmune diseases and the different effects of MLT are examined.

In our study; we could not find a statistically significant relationship between disease severity score and MLT levels. 
This may be due to the inclusion of a low number of FMF patients, low disease severity score, and disadvantages in evaluating the disease severity score. However, MLT levels were significantly higher in patients with arthritis history than those without arthritis. El-Awady et al. (25) reported that there was a significant relationship between the presence of arthritis, an indicator of disease activity score, and MLT levels in patients with RA, similar to our study. In a study, specific MLT binding sites and synovial fluid MLT levels were found to be high in synovial fluid macrophages of RA patients (10). In addition, it has been demonstrated in mice that exogenous MLT administration reported to increase the severity of arthritis (28). However, it is reported that MLT has anti-inflammatory and antioxidant effects by inhibiting the release of many proinflammatory mediators in many ways (24). It is not yet clear in the literature whether high serum MLT values are caused by arthritis or because of the need for more antioxidant activity or anti-inflammatory activity for compensatory purposes. Similar to studies in which inhibition of MLT synthesis or administration of antagonists has been reported to have a therapeutic effect as an adjuvant for RA (23), we think that it may have a positive effect on adjuvant therapy in FMF patients.

\section{Study Limitations}

The most important limitation of our study was that blood samples were obtained only between 8 and 9 am in the morning when MLT was the lowest and there was not a complete response to the circadian MLT release. In addition, we think that the number of patients is low and the results should be supported by studies in larger patient groups.

\section{Conclusion}

Our findings provide evidence that MLT plays a role in the immunopathogenesis of FMF and in those with a history of FMF-related arthritis. However, since the immune regulatory role of MLT is very complex and its mechanisms are not yet fully understood, we think that our findings should be supported by more comprehensive research in the future.

\section{Ethics}

Ethics Committee Approval: The study protocol was approved by the Atatürk University Faculty of Medicine Ethics Committee (decision no: 17, date: 07.11.2019).

Informed Consent: A written informed consent was obtained from each subject.

Peer-review: Internally peer-reviewed.

\section{Authorship Contributions}

Surgical and Medical Practices: A.K., N.Ö., K.S., F.B., Concept: A.K., N.Ö., Design: A.K., Data Collection or Processing: A.K., N.Ö, K.S., F.B., Analysis or Interpretation: A.K., N.Ö., Literature Search: A.K., Writing: A.K., N.Ö.

Conflict of Interest: No conflict of interest was declared by the authors
Financial Disclosure: The authors declared that this study received no financial support.

\section{References}

1. Sarı I, Birlik M, Kasifoğlu T. Familial Mediterranean fever: An updated review. Eur J Rheumatol 2014;1:21-33.

2. Stehlik C, Reed JC. The PYRIN connection: novel players in innate immunity and inflammation. J Exp Med 2004;200:551-8.

3. Simon A, van der Meer JWM. Pathogenesis of familial periodic fever syndromes or hereditary autoinflammatory syndromes. Am J Physiol Regul Integr Comp Physiol 2007;292:R86-98.

4. Gang N, Drenth JP, Langevitz P, Zemer D, Brezniak N, Pras M, et al. Activation of the cytokine network in familial Mediterranean fever. J Rheumatol 1999;26:890-7.

5. Sahin A, Erten S, Altunoglu A, Isikoglu S, Neselioglu S, Ergin M, et al. Comparison of serum oxidant and antioxidant parameters in familial Mediterranean fever patients (FMF) with attack free period. Acta Reumatol Port 2014;39:316-21.

6. Vgontzas AN, Chrousos GP. Sleep, the hypothalamic-pituitaryadrenal axis, and cytokines: multiple interactions and disturbances in sleep disorders. Endocrinol Metab Clin North Am 2002;31:1536.

7. Mormont MC, Levi F. Circadian-system alterations during cancer processes: a review. Int J cancer 1997;70:241-7.

8. Matsuo T, Yamaguchi S, Mitsui S, Emi A, Shimoda F, Okamura H. Control mechanism of the circadian clock for timing of cell division in vivo. Science 2003;302:255-9.

9. Korkmaz A. Melatonin as an adjuvant therapy in patients with rheumatoid arthritis. Br J Clin Pharmacol 2008;66:316-7.

10. Forrest CM, Mackay GM, Stoy N, Stone TW, Darlington LG. Inflammatory status and kynurenine metabolism in rheumatoid arthritis treated with melatonin. Br J Clin Pharmacol 2007;64:517-26.

11. Ha E, Choe B-K, Jung KH, Yoon SH, Park HJ, Park HK, et al. Positive relationship between melatonin receptor type $1 \mathrm{~B}$ polymorphism and rheumatoid factor in rheumatoid arthritis patients in the Korean population. J Pineal Res 2005;39:201-5.

12. Reiter RJ. Melatonin: clinical relevance. Best Pract Res Clin Endocrinol Metab 2003;17:273-85.

13. Musabak U, Kilciler G, Uygun A, Kantarcıoglu M, Polat Z, Sagkan $\mathrm{Rl}$, et al. Melatonin and Its Day and Night Rhythm of Alterations in Familial Mediterranean Fever: A Brief Research Letter. Open Rheumatol J 2011;5:13-7.

14. Livneh A, Langevitz P, Zemer D, Zaks N, Kees S, Lidar T, et al. Criteria for the diagnosis of familial Mediterranean fever. Arthritis Rheum 1997:40:1879-85.

15. Pras E, Livneh A, Balow JEJ, Pras E, Kastner DL, Pras M, et al. Clinical differences between North African and Iraqi Jews with familial Mediterranean fever. Am J Med Genet 1998;75:216-9.

16. Makay B, Unsal E. Altered circadian rhythm: possible trigger of familial Mediterranean fever attacks. Med Hypotheses 2009;73:630-1.

17. Arjona A, Sarkar DK. Evidence supporting a circadian control of natural killer cell function. Brain Behav Immun 2006;20:469-76.

18. Cutolo M, Otsa K, Aakre O, Sulli A. Nocturnal hormones and clinical rhythms in rheumatoid arthritis. Ann N Y Acad Sci 2005;1051:37281.

19. Pena C, Rincon J, Pedreanez A, Viera N, Mosquera J. Chemotactic effect of melatonin on leukocytes. J Pineal Res 2007;43:263-9.

20. Bagci S, Toy B, Tuzun A, Ates Y, Aslan M, Inal A, et al. Continuity of cytokine activation in patients with familial Mediterranean fever. Clin Rheumatol 2004;23:333-7.

21. Sav T, Ozbakir O, Kelestimur F, Gursoy S, Baskol M, Kula M, et al. Adrenal axis functions in patients with familial Mediterranean fever. Clin Rheumatol 2006;25:458-61.

22. Afkhamizadeh M, Sahebari M, Seyyed-Hoseini S-R. Morning melatonin serum values do not correlate with disease activity in rheumatoid arthritis: a cross-sectional study. Rheumatol Int 2014;34:1145-51

23. Baykal T, Senel K, Melikoglu M, Erdal A, Alp H, Ugur M. Melatonin Serum Levels in Rheumatoid Arthritis. FTR - Turkiye Fiz Tip ve Rehabil Derg 2013;59:42-4 
24. Sanchez A, Calpena AC, Clares B. Evaluating the Oxidative Stress in Inflammation: Role of Melatonin. Int J Mol Sci 2015;16:169817004.

25. El-Awady HM, El-Wakkad ASE-D, Saleh MT, Muhammad SI, Ghaniema EM. Serum melatonin in juvenile rheumatoid arthritis: correlation with disease activity. Pak J Biol Sci 2007;10:1471-6.

26. Senna MK, Olama SM, El-Arman M. Serum melatonin level in ankylosing spondylitis: is it increased in active disease? Rheumatol Int 2012;32:3429-33.
27. Zhao C-N, Wang P, Mao Y-M, Dan Y-L, Wu Q, Li X-M, et al. Potential role of melatonin in autoimmune diseases. Cytokine Growth Factor Rev [Internet] 2019;48:1-10. Available from: http://www. sciencedirect.com/science/article/pii/S1359610119300449

28. Treede R-D, Jensen TS, Campbell JN, Cruccu G, Dostrovsky JO, Griffin $J W$, et al. Neuropathic pain: redefinition and a grading system for clinical and research purposes. Neurology 2008;70:1630-5. 